\title{
The ACCuracy of Business English Curriculum to Students' COMMUnication Performance: The EFL StUdents' PERCEPTION
}

\author{
Pandu Prasodjo, Sabarina Moksin, Leil Badrah Zaki \\ Universitas Internasional Batam \\ pandu@uib.ac.id, moksin@uib.ac.id, leil@uib.ac.id
}

\begin{abstract}
Measuring the accuracy of a private university in Batam Business English course curriculum to the present needs of workplaces in Batam from students' perception is essential. Because $85 \%$ of the university students are working, it is compulsory to maintain the gap low between what students learned in class and what is implemented in the working field. A questionnaire consists of three dimensions (curriculum, communication performance, and motivation) distributed randomly to 60 students from a population $(\mathrm{N}=328)$ of the third-semester students programmed Business English course at a private university in Batam. The result suggested that the curriculum needs to add more practices, peer work, and case studies to improve students' communication performance. Students' perspectives in the Business English course reflected a new technical vocabulary that needed to practice in a correlated context. The curriculum content's relevance to the workplace's contextual needs is moderately related because not all working students used the English language in their workplace. Additional focus on internal and external motivation through group work and peer work is needed to improve students' communication performance and confidence. Finally, the existing Business English curriculum is reasonably accurate, supporting students' communication performance, both written and oral, at their workplace.
\end{abstract}

Keywords: Curriculum, ESP, EFL, Business English, students' perception

\section{INTRODUCTION}

Almost all sectors in human life today are affected by the development of information and communication technology (ICT). Since the late 70s, the Education field in language learning also could not escape to the vast inventions in ICT, it is reflected by the introduction of computer-assisted language learning (CALL) (Higgins, 1983). The development of CALL had many innovations in ICT-based teaching language today, such as flipped classroom (Bykonia et al., 2019; Flipped Learning Network, 2014; Jovanović et al., 2017; Wang, 2017), using social media (Lackovic et al., 2017; Thai et al., 2019; Wulandari, 2019; Xodabande, 2017), messenger applications (Hafifah \& Sulistyo, 2020; Mahzoun \& Zohoorian, 2019; Purnomo et al., 2016; Strasser, n.d.), and video games (Danka, 2020; Rivera-Trigueros \& Sánchez-Pérez, 2020; Tamtama et al., 2020).

Besides the education sector, other sectors in human life also adjusted to the vast growth of ICT, e.g. in business and manufacture (Kassem et al., 2019; Wahab et al., 2020), economy (González \& Nuchera, 2019; Jehangir et al., 2011; Ugli, 2020), tourism (Tu \& Hwang, 2020), etc. These studies showed that the implementation of ICT could improve output quality and increase working efficiency.

English for Specific Purposes (ESP) emerged around the 1960s (Johns \& Dudley-Evans, 1991) to prepare the English language competency in a specific discipline in terms of communication. ESP studies conducted in some disciplines, e.g., ESP for accounting (Sari \& Atmanegara, 2018), medical and nursing (Hosseini \& Shokrpour, 2019), engineering (Alsamadani, 2017; Arnó-Macià et al., 2020; Nimasari, 2018), and business (Amine \& Faiza, 2018; Fitria, 2019; Naukowy \& Polonijnej, 2018; Rahmi et al., 2020). The results showed that ESP is developed continuously through teaching materials, media, and curriculum design; to match graduates' needs to strive in working and global competition.

The curriculum development is needed to revisit periodically and match the targeted competencies, enhance collaborative and individual learning, and provide high-quality and relevant graduates as expected by future users in targeted sectors (Custodio et al., 2019). Notably, it is related to the ESP curriculum. Aspects covered in the curriculum development, e.g., defining objectives, contents, methodology, and evaluations (Hussain et al., 2011; Su, 2012). Therefore, the learning process's curriculum design could cover or come near to the relevant competencies expected by graduate users shortly.

Chan (2018) studied curriculum development in Business English ESP. He recommended more topic-specific, research-informed curriculum innovations in ESP be published to strengthen the link between research and curriculum development. Bykonia et al. (2019) added that students' preference in 
learning Business English shifted to a greater desire to engage independently with computer-assisted work, which affected how teachers' teaching strategy. Furthermore, Rahmi et al. (2020) investigated students' perceptions study in ESP Business English teaching implementation suggested that the appearance should be attractive to improve students' motivation using the book. Besides, teaching strategies provided fun learning, games, and controlled class is preferred for Indonesian learners.

Further study to measure the Business English curriculum's current accuracy to users' needs from students' perspectives who are working can enrich accurate information in developing the future curriculum supported by their knowledge of their workplace needs in English language communication performance. Therefore, research questions proposed are how do the students perceive the current Business English curriculum and how is the current Business English curriculum related to the students' communication performance in the working places.

\section{MATERIALS AND METHOD}

A survey was presented to collect data. The questionnaire consisted of 19 questions; 3 openquestions, 16 questions measured using Likert five-scale, determining 1 as the least or strongly disagree to 5 as the most or strongly agree. The questionnaire design consulted two scholars who are considered capable in statistics and designing the questionnaire. The questionnaire's internal consistency or reliability of questions with scaled answers was tested by piloting it with 25 representative samples distributed via the Google survey. 25 responses were received and analyzed. The questionnaire's reliability test resulted from a Cronbach's Alpha of 0.71. It is reflected that the instrument produced a reliable result (Mahzoun \& Zohoorian, 2019). The final design of the questionnaire was transferred to Google Form in order to be distributed online to the respondents.

The questionnaire was distributed randomly to 60 students who programmed Bussiness English $(\mathrm{N}=328)$ in a private university in Batam via a Whatsapp message containing a hyperlink to the Google Form. The population database was retrieved from the Academic Administrative and Student Affairs Bureau. The database accommodates students' names, study programs, email, and Whatsapp number.

The data collected from the open questions were analyzed and grouped into a relatively small number of categories (Krosnick \& Presser, 2010). Furthermore, an interview was conducted with five randomly selected students who were willing to for interview sessions. It is purposed for validating the categorical judgments (Lapan et al., 2012).

The interview was a semi-structural interview with open-ended questions conducted in Bahasa Indonesia for 15 to 30 minutes. The five students were interviewed three times a week with the same substance using different questions until the information is redundant or saturated (Lin, 2019; Perakyla, 2005)

The questionnaire and interview data were coded to present themes, representations, quotes, and comments summaries (deHaan, 2019) related to student's perceived values after the BE course.

\section{RESULTS AND DISCUSSION}

The questionnaire result was collected and analyzed accordingly. There were 72 responses recorded on the Google Form. There were 9 invalid responses because of double sending from the same respondent, besides 3 responses also invalid due to incomplete answering the questions. The screening process returned 60 valid responses and proceeded to the statistical calculation.

The students' feedback represented by the questionnaire (Table 1) is classified into three themes or indicators; those are 1) the relevance to the workplace, 2) the teaching and learning process, and 3) personal English communication performance.

Interview sessions were also conducted three times with five participants to validate the openended questions in the questionnaire and enrich the feedback collected through questionnaires. It was classified by themes, e.g., 1) the relevance of the BE curriculum; 2) The workplace expectations; 3) Students' motivations, and 4) Students' obstacles (Table 2). The number of interviews was considered already collecting saturated data on the third interview. No more new information could be gathered. Therefore, no further interview sessions were needed to be scheduled.

\begin{tabular}{|l|l|l|}
\hline No & Perceived Value & Percent \\
\hline 1 & $\begin{array}{l}\text { I feel the BE course improve my English } \\
\text { communication performance. }\end{array}$ & 83.00 \\
\hline 2 & My workplace uses the English language. & 76.00 \\
\hline
\end{tabular}




\begin{tabular}{|c|c|c|}
\hline 3 & $\begin{array}{l}\text { I found materials taught in BE helped me in the } \\
\text { workplace. }\end{array}$ & 83.67 \\
\hline 4 & The materials given in the $\mathrm{BE}$ course is challenging. & 85.00 \\
\hline 5 & $\begin{array}{l}\text { BE course accommodated me to explore my } \\
\text { creativity in learning English. }\end{array}$ & 84.33 \\
\hline 6 & $\begin{array}{l}\text { BE course gives exposure to my performance using } \\
\text { English. }\end{array}$ & 74.67 \\
\hline 7 & I can understand my friends who speak English. & 71.67 \\
\hline 8 & $\begin{array}{l}\text { My friends can understand me when I speak in } \\
\text { English. }\end{array}$ & 71.00 \\
\hline 9 & I can understand the English text. & 78.67 \\
\hline 10 & People can understand my English writing. & 76.00 \\
\hline 11 & I can use English grammar correctly. & 65.67 \\
\hline 12 & I am confident speaking in English. & 55.00 \\
\hline 13 & I am confident to write in English. & 58.33 \\
\hline 14 & I can do oral negotiation in English. & 44.67 \\
\hline 15 & $\begin{array}{l}\text { I can write a formal letter and a casual posting using } \\
\text { English. }\end{array}$ & 69.33 \\
\hline 16 & $\begin{array}{l}\text { I use English when visiting Singapore or other } \\
\text { countries }\end{array}$ & 63.33 \\
\hline
\end{tabular}

Table 1. Student's Perceived Value in BE Curriculum

\begin{tabular}{|l|l|l|}
\hline Theme & Representative Quote & $\begin{array}{l}\text { Summary of Related } \\
\text { Comment on the Topic }\end{array}$ \\
\hline $\begin{array}{l}\text { The relevance of } \\
\text { BE curriculum }\end{array}$ & $\begin{array}{l}\text { It was very helpful. } \\
\text { Thanks to the university for providing } \\
\text { this course. } \\
\text { I can implement what my lecturers } \\
\text { taught to my office worker. }\end{array}$ & $\begin{array}{l}\text { Participants agree that the } \\
\text { curriculum provided in the } \\
\text { BE course is relevant and } \\
\text { applicable to their } \\
\text { workplace/ office. }\end{array}$ \\
\hline $\begin{array}{l}\text { Workplace } \\
\text { expectations }\end{array}$ & $\begin{array}{l}\text { Communicate effectively to the } \\
\text { company/office international } \\
\text { partners/guests. }\end{array}$ & $\begin{array}{l}\text { The expectations of the } \\
\text { students' companies or } \\
\text { offices are students can } \\
\text { communicate effectively } \\
\text { even though just in basic } \\
\text { English performance. } \\
\text { Furthermore, performance in } \\
\text { handling and understanding } \\
\text { English text and commands } \\
\text { are preferable. For some big } \\
\text { companies, this performance }\end{array}$ \\
\hline
\end{tabular}




\begin{tabular}{|c|c|c|}
\hline & & becomes a compulsory. \\
\hline $\begin{array}{l}\text { Student's } \\
\text { motivation }\end{array}$ & $\begin{array}{l}\text { Sometimes, I am not confident } \\
\text { speaking in English because my } \\
\text { grammar is awkward. } \\
\text { Meeting international guests can force } \\
\text { me to use the English language and } \\
\text { improve it. } \\
\text { My BE lecturer gave me challenging } \\
\text { assignments to make an interview } \\
\text { video with overseas visitors in Batam. } \\
\text { I can use English to build my personal } \\
\text { branding on my Instagram. }\end{array}$ & $\begin{array}{l}\text { The problem could be } \\
\text { students' confidence. Even } \\
\text { though they speak in } \\
\text { English, not grammatical, } \\
\text { the intended meaning still } \\
\text { can be delivered. Besides, } \\
\text { visitors from Singapore who } \\
\text { often come to Batam at the } \\
\text { weekend could help to build } \\
\text { students' confidence by } \\
\text { giving compulsory } \\
\text { interaction practice. }\end{array}$ \\
\hline $\begin{array}{l}\text { Student's } \\
\text { obstacles }\end{array}$ & $\begin{array}{l}\text { Working in a small group can help me } \\
\text { finishing the assignments more } \\
\text { effectively than working in a big } \\
\text { group. }\end{array}$ & \\
\hline
\end{tabular}

Table 2. Reflections on the correlation of BE Curriculum and English used in the workplace

\section{II.1 Correlation of BE Curriculum to Current Workplace Expectations}

Based on the university Academic Administration and Students Affairs database, students who have jobs and working while studying is about $85 \%$ of the population. The stand of Bussiness English (BE) course taken by the students in a private university in Batam showed the satisfying result. The students feel that through the BE course, their communication performance in the English language is improving (87\%), which means that improvement could help students to give a better general performance on their job or career. This is validated by participants interviewed that by programming BE course they are insisted on learning something that could be applied at their workplace or office, e.g., greeting customers, writing offer letter, or responding the supervisor or employer instructions in the English language.

Not all students who are working using the English language in their workplace only $76 \%$ of students whose workplace using English in different range. The rest of them uses Bahasa Indonesia and the Chinese language as their daily official language. Even though in their workplace do not use the English language in their business, the benefit of taking BE course still could be applied. One participant said that,

"My office does not use English at all because our market is totally for local customers. Bahasa Indonesia and Mandarin (Chinese language) are more often used during the day. But for my English (language ability), I use it to build my personal branding in my social media Instagram, who knows, someone will use my account to promote their goods or services."

This phenomenon reflected that the BE course could apply not only to those who work in an office or company but also to those who use social media as social branding for business purposes. It could be a consideration for BE curriculum developers to start looking at the digital business, e.g., English for social media branding, as one enrichment topic in the curriculum. Added by Taillefer, (2018), besides the basic fundamental ESP curriculum, technological issues and digital materials become challenges for the curriculum development to tackle.

\section{II.2 Student' Perceived Values to Existing BE Curriculum}

The perceived values of the BE course were investigated in two dimensions, and those are the teaching and learning process and personal English communication performance.

The teaching and learning process conducting under the same BE curriculum was designed by the curriculum developers. It is distributed to lecturers who are assigned to teach BE. A preliminary interview was conducted with the $\mathrm{BE}$ course coordinator related to the mechanism of running the $\mathrm{BE}$ course in multiple classes. At the beginning of the semester, the BE coordinator invited all BE lecturers 
to have a briefing discussing the current curriculum and the targeted outputs in the BE course. Therefore, BE lecturers shared the same targets and outcomes.

The students' perspectives in the teaching and learning process shared high relevant values to the indicators measured respectively.

Most students agree that the teaching materials prepared for the students in the BE course are challenging to explore their creativity and giving exposure in improving their English communication performance that possibly applied at their workplace. From the interview of a participant, she said that she does not sound confident enough to speak in English because her English grammar had to improve much. After programming the BE course, she thought that the BE could motivate her to advance the grammar in English.

Besides, their job was one of the reasons they programmed the BE course. At their office or company, their positions required them to interact with international customers, companies, and guests.

On the other hand, obstacles issue also raised by students in the process of teaching and learning. It was related to the grouping management. A validation conducted by interviewing participants that this issue could decrease the effectiveness of learning BE because most of the students are working, they do not have much time to have a regular discussion session and, usually, the group working load was handled by one or two group members only. It is suggested to have a smaller group to work with.

The students' perceived their personal English communication performance improving after conducting the BE course is moderately agree. It showed that less than $60 \%$ of the students are not confident both in performing speaking and writing in English. Even though they could do conversation practices and understand what their friend says in English, they also could write a formal letter as required in the course curriculum, and some of them practiced it in their workplace.

Augmenting the development of BE curriculum by adding confidence issues, e.g., settings (Hashim \& Yunus, 2018), teaching contents, or strategies (Dewi et al., 2016; Singhanuwananon, 2016), in performing English both oral and written could become a consideration. Due to the number of students who are self-assured performing English to communicate is still below $60 \%$.

\section{CONCLUSION}

The students' perceived value after completing BE course related to the relevance of the existing $\mathrm{BE}$ curriculum to the expected output by the graduates' users are relatively relevant to be conducted to higher education students because it could accordingly help them in their workplace, especially to students who work at big companies in Batam which closely linked with other international companies or to those who work or running on tour and travel business. The practical issues brought by students to the class could be a real-case discussion enrichment material for the students, lecturers, and curriculum development.

Raising students' confidence becomes a decisive issue as a special proposition to put in the curriculum development alongside the core English skills.

Further studies on investigating proper and effective BE curriculum that relevant to the current needs and could increase students' confidence perform English both oral and written. Furthermore, this study data is very limited due to taken participants that come from one private university in Batam. Collecting data from a broader participant could increase the accuracy for inferring the result to a broader scope.

\section{REFERENCES}

Alsamadani, H. A. (2017). Needs analysis in ESP context: Saudi engineering students as a case study. Advances in Language and Literary Studies, 8(6), 58-68.

Amine, B., \& Faiza, S. (2018). the Effect of Process- Genre Approach on ESP Students'. European Journal of Research and Reflection in Educational Sciences, 6(2), 10-14.

Arnó-Macià, E., Aguilar-Pérez, M., \& Tatzl, D. (2020). Engineering students' perceptions of the role of ESP courses in internationalized universities. English for Specific Purposes, 58, 58-74. https://doi.org/10.1016/j.esp.2019.12.001

Bykonia, O. P., Borysenko, I. V., Zvarych, I. M., Harbuza, T. V., \& Chepurna, M. V. (2019). Teaching business English to future economists using a multimedia textbook. International Journal of Higher Education, 8(4), 115-123. https://doi.org/10.5430/ijhe.v8n4p115 
Chan, C. S. C. (2018). Proposing and illustrating a research-informed approach to curriculum development for specific topics in business English. English for Specific Purposes, 52, 27-46. https://doi.org/10.1016/j.esp.2018.07.001

Custodio, P. C., Espita, G. N., \& Siy, L. C. (2019). The Implementation of Outcome-Based Education at a Philippine University. Asia Pacific Journal of Multidisciplinary Research, 7(4), 37-49. www.apjmr.com

Danka, I. (2020). Motivation by gamification: Adapting motivational tools of massively multiplayer online role-playing games (MMORPGs) for peer-to-peer assessment in connectivist massive open online courses (cMOOCs). International Review of Education, 66(1), 75-92. https://doi.org/10.1007/s11159-020-09821-6

deHaan, J. (2019). Teaching language and literacy with games: What? How? Why? Ludic Language Pedagogy, 1, 1-57.

Dewi, R. S., Kultsum, U., \& Armadi, A. (2016). Using Communicative Games in Improving Students' Speaking Skills. English Language Teaching, 10(1), 63. https://doi.org/10.5539/elt.v10n1p63

Fitria, T. N. (2019). Business English As A Part Of Teaching English For Specific Purposes (ESP) To Economic Students. Jurnal Education and Economics, 02(02), 143-152. http://jurnal.azharululum.sch.id/index.php/jee/article/view/51

Flipped Learning Network. (2014). What Is Flipped Learning? The Four Pillars of F-L-I-P. Flipped Learning Network.

González, R. L. H., \& Nuchera, A. H. (2019). Dynamics of service innovation management and cocreation in firms in the digital economy sector. Contaduria y Administracion, 64(1), 1-19. https://doi.org/10.22201/fca.24488410e.2018.1802

Hafifah, G. N., \& Sulistyo, G. H. (2020). Teachers' ICT literacy and ICT integration in ELT in the Indonesian higher education setting. Turkish Online Journal of Distance Education, 21(3), 186198. https://doi.org/10.17718/TOJDE.762050

Hashim, H. U., \& Yunus, M. M. (2018). English as a Second Language (ESL) Learning: Setting the Right Environment for Second Language Acquisition. Tadris: Jurnal Keguruan Dan Ilmu Tarbiyah, 3(2), 207. https://doi.org/10.24042/tadris.v3i2.2941

Higgins, J. (1983). Computer-assisted language learning. Language Teaching, 16(2), 102-114. https://doi.org/10.1017/S0261444800009988

Hosseini, A., \& Shokrpour, N. (2019). Exploring motivating factors among Iranian medical and nursing ESP language learners. Cogent Arts and Humanities, 6(1). https://doi.org/10.1080/23311983.2019.1634324

Hussain, A., Dogar, A. H., Azeem, M., \& Shakoor, A. (2011). Evaluation of Curriculum Development Process. International Journal of Humanities and Social Science, 1(14), 263-271. http://www.ijhssnet.com/journals/Vol_1_No_14_October_2011/34.pdf

Jehangir, M., Dominic, P. D. D., Naseebullah, \& Khan, A. (2011). Towards digital economy: The development of ICT and E-commerce in Malaysia. Modern Applied Science, 5(2), 171-178. https://doi.org/10.5539/mas.v5n2p171

Johns, A. M., \& Dudley-Evans, T. (1991). English for Specific Purposes: International in Scope, Specific in Purpose. TESOL Quarterly, 25(2), 297. https://doi.org/10.2307/3587465

Jovanović, J., Gašević, D., Dawson, S., Pardo, A., \& Mirriahi, N. (2017). Learning analytics to unveil learning strategies in a flipped classroom. The Internet and Higher Education, 33, 74-85. https://doi.org/10.1016/j.iheduc.2017.02.001

Kassem, R., Ajmal, M., Gunasekaran, A., \& Helo, P. (2019). Assessing the impact of organizational culture on achieving business excellence with a moderating role of ICT: An SEM approach. Benchmarking, 26(1), 117-146. https://doi.org/10.1108/BIJ-03-2018-0068

Krosnick, J. A., \& Presser, S. (2010). Question and Questionnaire Design. In Handbook of Survey Research, Second Edition (Second). Emerald Group Publishing Limited. https://doi.org/10.1097/01.PRS.0000074494.47391.BE

Lackovic, N., Kerry, R., Lowe, R., \& Lowe, T. (2017). Being knowledge, power and profession subordinates: Students' perceptions of Twitter for learning. The Internet and Higher Education, 33, 41-48. https://doi.org/10.1016/j.iheduc.2016.12.002

Lapan, S., Quartaroli, M. T., \& Riemer, F. J. (2012). Qualitative Research: An Introduction to Methods and Designs (S. Lapan, M. T. Quartaroli, \& F. J. Riemer (eds.)). Jossey-Bass. file://C:/Users/youhe/Downloads/kdoc_o_00042_01.pdf 
Lin, S.-F. (2019). Students' Attitudes Towards Learning English Vocabulary Through Collaborative Group Work Versus Individual Work. Journal of Education and Learning, 8(4), 93. https://doi.org/10.5539/jel.v8n4p93

Mahzoun, F. E., \& Zohoorian, Z. (2019). Employing telegram application: Learners' attitude, vocabulary learning, and vocabulary delayed retention. European Journal of Foreign Language Teaching, 4(1), 151-165. https://doi.org/10.5281/zenodo.2651380

Naukowy, P., \& Polonijnej, A. (2018). COMPETANCY-BASED APPROACH TO TEACHING ENGLISH FOR SPECIFIC PURPOSES (ESP) AND BUSINESS ENGLISH (BE) Olga. Periodyk Naukowy Akademii Polonijnej, 27(2), 28-35.

Nimasari, E. P. (2018). An ESP Needs Analysis: Addressing the Needs of English for Informatics Engineering. JEES (Journal of English Educators Society), 3(1), 23. https://doi.org/10.21070/jees.v3i1.1085

Perakyla, A. (2005). Analyzing Talk and Text. In Handbook of Qualitative Research. https://doi.org/10.1017/CBO9781107415324.004

Purnomo, A., Ratnawati, N., \& Aristin, N. F. (2016). Pengembangan Pembelajaran Blended Learning Pada Generasi Z. Jurnal Teori Dan Praksis Pembelajaran IPS.

Rahmi, R., Abduh, A., \& Sofyan, M. (2020). Student Perception of ESP Business English Teaching Implementation in Makassar National Informatics Polytechnic. Jurnal Ad'ministrare, 6(2), 167. https://doi.org/10.26858/ja.v6i2.12514

Rivera-Trigueros, I., \& Sánchez-Pérez, M. M. (2020). Conquering the iron throne: Using Classcraft to foster students' motivation in the EFL classroom. The Journal of Teaching English with Technology, 20(2), 3-22.

Sari, F., \& Atmanegara, Y. (2018). Developing ESP Reading Materials for Accounting Students. Advances in Language and Literary Studies, 9(5), 1. https://doi.org/10.7575/aiac.alls.v.9n.5p.1

Singhanuwananon, S. (2016). Intelligibility Redefinition and Students' Confidence in English Speaking in Thai Elt. European Journal of Sustainable Development, 5(4), 209-215. https://doi.org/10.14207/ejsd.2016.v5n4p209-215

Strasser, T. (n.d.). App, app' n' away. How social messaging tools like WhatsApp support mobile language learning and teaching. 2020, 25-55.

$\mathrm{Su}, \mathrm{S} .-\mathrm{W}$. (2012). The Various Concepts of Curriculum and the Factors Involved in Curricula-making. Journal of Language Teaching and Research, 3(1). https://doi.org/10.4304/jltr.3.1.153-158

Taillefer, L. (2018). A Business English Course in the Digital Era: Design and Analysis (pp. 165-182). https://doi.org/10.1007/978-3-319-68926-5_11

Tamtama, G. I. W., Suryanto, P., \& Suyoto. (2020). Design of english vocabulary mobile apps using gamification: An Indonesian case study for kindergarten. International Journal of Engineering Pedagogy, 10(1), 105-162. https://doi.org/10.3991/ijep.v10i1.11551

Thai, M., Sheeran, N., \& Cummings, D. J. (2019). We're all in this together: The impact of Facebook groups on social connectedness and other outcomes in higher education. Internet and Higher Education, 40(April 2018), 44-49. https://doi.org/10.1016/j.iheduc.2018.10.001

Tu, Y.-F., \& Hwang, G.-J. (2020). Trends and research issues of mobile learning studies in hospitality, leisure, sport and tourism education: a review of academic publications from 2002 to 2017. Interactive Learning Environments, 28(4), 385-403. https://doi.org/10.1080/10494820.2018.1528285

Ugli, A. N. R. (2020). The Role of Digital Economy and ICT in Developing Economics of Uzbekistan. International Journal of Research \& Development, 5(3), 31-33.

Wahab, N. Y. A., Mohamad, M., Yusuff, Y. Z., \& Musa, R. (2020). The importance of ICT adoption in manufacturing sector: An empirical evidence on SME business performance. International Journal of Supply Chain Management, 9(2), 268-272.

Wang, F. H. (2017). An exploration of online behaviour engagement and achievement in flipped classroom supported by learning management system. Computers \& Education, 114, 79-91. https://doi.org/10.1016/j.compedu.2017.06.012

Wulandari, M. (2019). Improving Efl Learners' Speaking Proficiency Through Instagram Vlog. Journal: A Journal on Language and Language Teaching, 22(1), 111-125. https://doi.org/10.24071/11t.2019.220111

Xodabande, I. (2017). The effectiveness of social media network telegram in teaching English language pronunciation to Iranian EFL learners. Cogent Education, 4(1). https://doi.org/10.1080/2331186X.2017.1347081 
